\title{
Sufism In The Novel: Cat's Eyes
}

Nayera Miniawi, Ph.D., Princess Alia University College, Al Balqa Applied University, Jordan

\begin{abstract}
Cat's Eyes is a novel about suffering and endurance, early marriage, spirituality and the sanctuary it provides, and Sufism in particular. It uses certain motifs to depict the psychological suffering of a young girl, caused by her conservative father and unsatisfactory marriage, which persists until she finally reaches a moment of spiritual clarity. This paper focuses primarily on how this novel's motifs illustrate the revelatory power of Sufism's unifying worldview.
\end{abstract}

Keywords: Sufism; Cat's Eyes; Suffering; Spirituality

\section{INTRODUCTION}

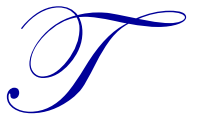

he novelist Dr. Shilla al-Augaly, who is half-Syrian and half-Jordanian, spent three years studying the Sufi movement. This study became the kernel for her novel, Cat's Eyes, the story of the life of Ayouba, whose name is an obvious allusion to the name "Ayoub," or Job, with all its connotations of patient endurance of suffering that continues until salvation finally arrives. In the novel, when Ayouba finally finds salvation, she says, "I've become prettier; I've become more crystallized. . . . And my heart. . . became bigger and enduring" (p. 107). Here, two highly connotative verbs deserve notice: the verb "crystallize," which means to form into crystals, and the verb "endure." This latter verb suggests a theme of endurance that has continued since the beginning of the story, which details Ayouba's childhood suffering, inflicted on her by her despotically cruel father. Ayouba hates her father for mistreating her, her mother, and her sisters - she does not have any brothers. From the perspective of her childhood self, Ayouba describes her father as follows: "He erupts with rage all over again, and like an ox he bolts at us. How ugly his countenance, his eyes bulging out of their sockets, his nose, his mouth. I hate him..." (p. 52).

The time she spends in school and playing with her peers, especially her schoolmate, Ali, becomes her only sanctuary from the cruelty of her domestic life. However, even this sanctuary is taken from her when her father interrupts her education, forcing her to wear a head covering even before she reaches puberty, and making her stay home until she can be married and he can be rid of her. As a result, Ayouba lurches forward into her adult life and falls into an inequitable marriage that gives her no satisfaction, neither sexually or emotionally. This dissatisfaction intensifies her constant psychological and physical suffering, which continues until, one day, she climbs to the roof of her house to watch Sufi practices and rituals; she witnesses prayers of entreaty, songs of worship, and a circular dance accompanied by spiritual music that seizes her attention, leading her into a state of transcendence. This special music, enhanced by an array of colors and lights, illuminates Ayouba's vision and helps her transcend the pain in her life.

Cat's Eyes has two main characters, both of whom shape the narrative. First, there is the employed, educated, and cultured narrator who is always commuting between Halab (Syria), Amman (Jordan), and Dubai. Second, there is Ayouba, the suffering girl who becomes a woman who finds peace and sanctuary through watching Sufi rituals and enjoying the circular dancing that is accompanied by religious singing and prayers, all of which occur in a colorful atmosphere bathed in light and surrounded by an aura of illumination. Ayouba's newfound spiritual disposition improves her life. As noted above, her name is the feminine form of the name of the prophet "Ayoub" or Job. It means "the patient one," which reflects the fact that Ayouba, like the prophet, has to endure pain until release and salvation arrive as a result of her deep faith and the devout work she does to immerse herself in a world of rosaries made of beads and precious stones. 
Moreover, rosaries are tools conventionally used for prayer. Despite their material nature and the physical solidity that comes from the fact that they are made of stone, they can endow a devout person with the sanctity needed to pray and worship sincerely and for that person's soul to transcend daily life and rise to a more spiritual sphere, one far away from the narrow limitations of the body, matter, and materialism. Later in the novel, Ayouba describes the effect of her spiritual experience in various ways; understanding her reaction to what she sees shows the great importance Sufism has in this novel: "A world full of bright colors, that deceives the eye and diverts the vision. . . a world of lights and music!? Everything in the world of rosaries concerns me, the yarn. . . the colored beads" (p. 106). She continues,

This world immerses me in meditations and questions. . I invent a new world ... . [S]tones in various shapes, cuts and sizes, colored in a way I never set my eyes on before! There is no single blue, red, yellow, green, and grey color. ... It is a world of colors. . [a] world of beads. . the further I tread into those obscurities the further my love for the earth the sky and the sea increases, and the further I became closer to their Maker.

Ayouba gives additional descriptions of moments of spiritual clarity, saying: "the voice captivated me, and the event he narrates took me out of my place to the sky, to the past or the promised future after death" (p. 83). She also observes,

[A] long time passed but the voices continued. . at times they sang, and at times. . they turned into a tenor. . they were masculine voices. . a very melodious singing. . they are men praising God (p. 81).

Then she adds,

Overlapping loops of men dressed in white. . they seemed to the beholder like an overlapping wreaths of jasmine. . . the whole spectacle inspired purity and security. Wrapped in greenery, running blessed waters, whiteness, and the moon; the lights from the sky and the earth.

Elsewhere in the novel, Ayouba describes a group of Sufis, saying,

A group of men dressed in peculiar attires, white gowns tight from the top and loose from the waist below. . their spinning sped up and their gowns flourished to their full extent like jasmine flowers, their singing and dancing grew higher. . . and I saw them flowers, butterflies, and birds, going round and round with arms raised to the sky in supplication... The scene fascinated me. I began to move nimbly, twirling on one tap to another, as if my body has left me and threw itself amongst them ... my body surprised me! Yes I was dancing like a mad woman.

To better understand what Ayouba has done and what has happened to her, it may be necessary to stop here and consider Sufism itself. How did it start? Moreover, in what ways do Ayouba's actions reflect the actions of Sufism's founder, Jalal a'den al- Rumi (1207-1273)'? When Rumi, who was a great poet, learned of the death of his friend at the hands of his envious enemies, he wore his mourning attire and went out on the streets of Konya in Turkey, crushed by sadness. While passing by a certain street, he heard the sound of gold being hammered and, with every blow, he heard the name of God being said. At that, he spread his arms out and began to spin around incessantly and continued from noon until dusk. He felt no fatigue and, instead, became invigorated by his circular movement, feeling an unusual spiritual power resulting from it. The same happened to Ayouba, when she spun around imitating what she heard and saw in Sufi rituals. The essence of Sufism is love, beauty, poetry, music, and contemplation of the unity of creation and the continuity of the relation between God and creature, and heaven and earth.

The Sufi practice something called "kholah." They do this by consecrating themselves through spending uninterrupted time in total seclusion, so that they will not be distracted by mundane realities and will instead be compelled to focus on spirituality and prayer until they become fully attuned to their own heartbeats.

Ayouba, made so desolate by her miseries that she has lost her ability to feel happiness, was in a way prepared to respond to existential Sufi vibrations emanating from the ether around her. In the Sufi rituals Ayouba observes, the dervishes, ascetics who have taken a vow of poverty, gather together in what is called "sam'a khaneh," 
and then they begin repeating the name of God while continuously moving their bodies in rhythm with their prayers, music, and chants. Circling is the basic movement made during such gatherings, as this produces a feeling of lightness and gives the human body a sense of elevation, as if it is traveling up through space toward heaven. When Ayouba describes the praise circle, this is the behavior and sensations to which she refers. She likens the people she sees to birds or butterflies enveloped in a perfume that smells like a jasmine wreath. The dancers are dressed in their traditional white gowns, which symbolize funeral palls and emphasize how life and death intersect at a single point.

The circular movement, as well as the shape of the circle itself, represents the relationship between beginning and end, acting as an intermediary. Rotating around a center that symbolizes the earth is an act that unifies man, his maker, earth, and heaven, since earth, plants, and stars all rotate around the sun just as the disciples rotate around their Sufi master. The circular movement praises the greatness of God. The praise of all creation, including man, tree, bird, and beast, with all their lights and colors, is reflected in these gatherings. Ayouba's recognition of the meaning behind these symbolic actions leads her to become obsessed with gemstones, their various colors, and polished shapes. Putting rosaries together allows Ayouba to work with such gemstones. Gemstones are also subtly referenced by the novel's title, Cat's Eyes, which consists of two nouns, the first of which, eye, is the organ used for seeing and not sight.

In the novel, a man says to Ayouba, "This is cat's eyes. It is yours." She replies, "This is the first time I have ever owed a stone." Then she qualifies this, saying that except for her cat's eyes, she has owned a stone, but it was a fake one" (p. 132).

The other word, cat, refers to an animal with shiny glittery eyes that reflect light at night. Although it is often a domesticated animal, it can be insidious and viscous at times and has been known to eat its own offspring. In a sense, in this novel, Ayouba is the wide-eyed kitten who has been wronged as both a child and an adult.

\section{CONCLUSION}

Early in the novel, the narrator portrays Ayouba in a way that gives her a mythical presence, describing her dressed in her black gown and her head covering, which she has decorated with fake gemstones, wearing Sinbad shoes (13). At the end of the novel, Ayouba gives a description of herself that mirrors the narrator's, speaking of her long black gown and silken head covering decorated with fake necklaces and gemstones. This gives the novel a sense of unity, as does the following parallel between beginning and end. When the novel begins, the narrator has just met Ayouba in a market in Dubai. At the end, the narrator gives a description of Ayouba in a market in Halab identical to the one described in the beginning.

According to Sufi belief, history completes itself when life ends where it began. Moreover, all of this relates to gemstones, as stones come from the earth and the earth is dust. God breathed into that dust; thus, man was made and to dust he shall return. "We began with a candle stick and prayer, and we finished with a candle stick and a prayer" (p. 183). It is this cycle of life that Cat's Eyes ultimately illustrates.

\section{AUTHOR INFORMATION}

Nayera Miniawi, Ph.D., Princess Alia University College, Al Balqa Applied University, Jordan

\section{REFERENCES}

1. al Ajeli, Shaala (Dr.). The Cat's Eye. Arab Institute For Research and Publishing, Beirut.2000, New edition 2003.

2. Abu - Lughod, Lila. Remaking Women- Feminism and Modernity in the Middle East. The American University in Cairo. Cairo/Egypt. 1998.

3. Ahmed, Leila. Women and Gender in Islam. Yale University Press .New Haven and London. 1992.

4. $\quad$ Ashour, Radwa, Ferial J. Ghazoul \& Hasna Reda-Mekdashi (eds.).Arab Women Writers- A Critical Reference Guide 1873-1999.The American University in Cairo Press \& Syracuse University Press. Cairo/Egypt \& U.S.A. 2007. 
5. Badran, Margot. Feminism in Islam - Secular and Religious Convergences. Oneworld. Oxford. 2011.

6. Sedgwick, Mark J., Sufism: The Essentials. American University in Cairo Press. Cairo/Egypt. $2000,2003$.

7. Shaaban, Bouthaina. Voices Revealed-Arab Women Novelists 1898-2000. Lynne Reinner Publishers.

Boulder, London. 2009. 